doc. dr. sc. Senka Borovac Zekan¹

Katarina Gabrić, bacc.oec. ${ }^{2}$

\title{
NEVERBALNA KOMUNIKACIJA KAO ALAT UVJERAVANJA U JAVNOM NASTUPU
}

\author{
Stručni rad / Professional Paper \\ UDK/UDC: 159.925 .8 \\ DOI: 10.51650/ezrvs.15.3-4.11 \\ Primljeno / Received: 4/10/2021 \\ Prihvaćeno / Accepted: 11/11/2021
}

U svakodnevnoj komunikaciji, svjesno ili nesvjesno, koristimo se neverbalnom komunikacijom kako bismo prenijeli poruku sugovorniku na što efektivniji način, izrazili emocije, dojmove ili ga uvjerili u vlastite stavove. Neverbalna komunikacija podrazumijeva kontakt očima, izraz lica, stav i položaj tijela, gestikulaciju rukama, ton glasa kao i dodir. Osobni izgled također spada u jednu vrstu neverbalne komunikacije. Stil odijevanja ostavlja dojam na sugovornike koji može imati veliki utjecaj na cjelokupno izlaganje. Javni govor podrazumijeva izlaganje određenih informacija većoj skupini slušatelja. Takvo izlaganje može biti pripremljeno, nepripremljeno, formalno, neformalno, spontano ili pak strukturirano. Kod javnog govora osim verbalnih veliki značaj imaju i neverbalni parametri izlaganja. Oni predstavljaju ključan alat korišten kako bi, ne samo uvjerili slušatelje u pouzdanost $i$ ispravnost onoga što se govori, već kako bi pridobili njihovu pažnju sa ciljem da interes slušatelja ostane prisutan tijekom cijelog izlaganja. Iz navedenog razloga neverbalna komunikacija je izuzetno bitna kao predmet izučavanja u sklopu tematike javnog nastupa. Ukupna neverbalna komunikacija kao i govorne sposobnosti mogu se vježbanjem usavršiti. Korištenjem različitih tehnika uvjeravanja moguće je utjecati na slušatelje i približiti im stavove i poruku koja im se pokušava prenijeti. Ovim radom nastojao se istražiti utjecaj neverbalne komunikacije kao alata uvjeravanja u javnom nastupu. U radu se analizira kakav i koliki utjecaj ima neverbalno izražavanje na cjelokupni dojam o govorniku. Empirijski dio rada temelji se na analizi mišljenja i stavova ispitanika prikupljenih anketom o neverbalnoj komunikaciji. Rezultati dobiveni obradom anketnog upitnika ukazuju kako neverbalno izražavanje ima znatan utjecaj na cjelokupni dojam o osobi koja javnim govorom prenosi određenu poruku. Stečeni dojam u konačnici može ostaviti generalno negativan ili pozitivan stav o govorniku te se potvrdila činjenica kako neverbalna komunikacija često ostavlja snažniji dojam na stav slušatelja o govorniku od verbalne komunikacije.

Ključne riječi: neverbalna komunikacija, javni nastup, alati uvjeravanja everbalna komunikacija, javni nastup, alati uvjeravanja.

\footnotetext{
1 Sveučilišni odjel za stručne studije u Splitu, e-mail: sborovac@oss.unist.hr

2 Sveučilišni odjel za stručne studije u Splitu, e-mail: kg45903@oss.unist.hr
} 


\section{Uvod}

Komunikacija podrazumijeva izgradnju odnosa među ljudima, bilo da se radi o komunikaciji između dvije osobe ili stotinama osoba. Ona predstavlja važan preduvjet za kvalitetu svih društvenih odnosa. Treba spomenuti kako u literaturi postoje različite definicije komunikacije. Uglavnom, sve one naglašavaju činjenicu kako je: „komunikacija proces razmjene misli i poruka koji se odvija između dvoje ili više ljudi. " (Lučanin, 2010). Još davne 1967. godine Mehrabian, A. baveći se tematikom komunikacije ustvrdio je kako značajan dio cjelokupne komunikacije predstavlja neverbalna komunikacija. Zastupljenost neverbalne komunikacije u ukupnoj komunikaciji iznosi visokih 93\%. Na govor tijela odnosi se čak 55\% dok glasovna intonacija predstavlja $38 \%$. U slučaju da se verbalna i neverbalna komunikacija ne „poklapaju“ odnosno ne uspijevaju prenijeti istu poruku, istraživanja su pokazala kako će slušatelj uvijek više vjerovati neverbalnoj komunikaciji. Do navedenog dolazi jer je neverbalnu komunikaciju teže kontrolirati od verbalne komunikacije. Neverbalna komunikacija ima za cilj „poduprijeti“ verbalnu poruku. Ona uključuje izraz lica, kontakt očima, položaj i stav tijela, gestikulaciju dijelovima tijela, glasovnu intonaciju i fizički dodir. Neverbalno se komunicira i osobnim izgledom. Stilom odijevanja govornik ostavlja dojam na druge. Ovo je posebno važno pri javnom nastupu i govoru jer stil odijevanja utječe na konačan stav slušatelja o govorniku. Kroz povijest se govorništvo koristilo kao ključno sredstvo komunikacije. Govor je način javnog izražavanje vlastitih mišljenja i ideja s drugim ljudima. Svaka situacija javnog obraćanja publici može se nazvati javnim govorom. Glavni cilj javnog nastupa je poslati jasnu poruku i prevladati strah od javnog nastupa kako bi govornik djelovao uvjerljivo. U cilju javnog nastupa, da bi se komunikacija ocijenila uspješnom, potrebno je da verbalna i neverbalna komunikacija govornika budu usklađene (Španjol-Marković, 2008). Neverbalna komunikacija u javnom govoru odnosi se na način na koji se neverbalni znakovi koriste za prenošenje željene poruke. Govornik se treba prilagoditi publici kojoj se obraća, a njegov govor treba biti što prirodniji i zanimljiviji. Govornici u javnosti često zanemaruju neverbalne geste tijekom javnih nastupa, te stoga ostavljaju loš dojam na publiku. Javni nastup trebao bi se sastojati od tri dijela: uvodnog, glavnog i završnog dijela (Petar, 2009.). Uobičajeno je da se unaprijed dogovoren javni govor priprema unaprijed. Govornik nastoji uskladiti sve elemente javnog nastupa s tematikom govora i publikom kojoj se obraća. Stoga prilikom izlaganja javnog govora, osim verbalne pripreme, potrebno je izvršiti i pripremu vezanu uz neverbalni dio nastupa. Neverbalni elementi nastupa su ključan alat koji se koristi kako bi, ne samo uvjerili slušatelje u pouzdanost $\mathrm{i}$ ispravnost onoga što govornik nastoji prenijeti slušateljstvu, već kako bi pridobili njegovu punu pažnju s ciljem zadržavanja interesa slušatelja tijekom cijelog izlaganja. Ne postoji uspješan javni govor kojeg ne prati učinkovita neverbalna komunikacija. Iz navedenog slijedi kako je neverbalna komunikacija iznimno bitan element javnog nastupa i kao takav predmet je brojnih izučavanja. Glavni cilj ovog rada bio je utvrditi kako su ispitanici protumačili znakove neverbalne komunikacije na prikazanom video sadržaju javnog nastupa bivše predsjednice Kolinde Grabar Kitarović i u kojoj mjeri su navedeni znakovi utjecali na njihov ukupan dojam o njenom javnom govoru. 


\subsection{Vrste komunikacija}

Verbalna komunikacija odnosi se na usmeno izražavanje i uvijek je determinirana određenim socijalnim utjecajem ( $\mathrm{Ng}$, Bradac, 1993). Osoba se može verbalno izražavati samostalno (učenjem na glas, glasnim razmišljanjem i slično) ili u prisutnosti jednog ili više slušatelja. Neverbalna komunikacija se manifestira na različite načine. Može, između ostalog, uključivati sve prethodno navedene simbole i signale. Ona također obuhvaća i dodir, gestikulaciju rukama, položaj tijela, kontakt očima i izraz lica. Paraverbalna komunikacija odnosi se na ton glasa, intonaciju (od latinski intonare: podizati glas) ${ }^{3}$, način izgovora, ritam i druge karakteristike vezane uz glas. Osim spomenutih razlikuje se i interpersonalna komunikacija, intrapersonalna komunikacija, grupna komunikacija, masovna komunikacija i aktivno slušanje kao poseban oblik komunikacije. No one nisu predmet istraživanja ovog rada te in se neće pobliže objašnjavati.

\subsubsection{Verbalna komunikacija}

Ovaj oblik komunikacije opisuje jezično izražavanje. Može se manifestirati kroz govor ili pismo. Govor i slušanje su osnovni preduvjeti potrebni kako bi došlo do verbalne komunikacije. Verbalna komunikacija se može direktno kontrolirati. Navedeno znači kako prilikom držanja govora osoba točno zna što će reći i na koji način će se izraziti dok kod neverbalne komunikacije osoba ne može u potpunosti utjecati na to kako će se izraziti jer se ona većim dijelom događa na nesvjesnoj razini pojedinca. Kultura također utječe na način verbalnog izražavanja. Po strukturi verbalna komunikacija ima definiranu gramatiku i izraze, odnosno riječi, i po tome se, između ostalog, razlikuje od neverbalne komunikacije. Neverbalna komunikacija često može biti protumačena drugačije po svojoj strukturi. Primjer toga je iznenađenost koja može biti i negativna ali i pozitivna. Verbalna komunikacija može se razviti i unaprijediti edukacijom. Brojna su istraživanja, posebno u medicini, potvrdila navedenu tvrdnju (Brindley, Reynolds, 2011). Pojedinac uči kako usvojiti različite strukovne izraze koji su mu do tada bili nepoznati, što se odražava i na način izražavanja koji time postaje kvalitetniji. Kod verbalne komunikacije posebno se ističe važnost slušanja. Kada je slušatelj usredotočen na sadržaj onoga što mu govornik nastoji prenijeti, jednostavnije će mu biti pružiti povratnu informaciju, postaviti pitanje i sl. Kod verbalnog komuniciranja važno je da ono bude usklađeno s neverbalnim. Poželjno je, primjerice, govornika ili slušatelja gledati u oči. Na taj način mu se neverbalnom komunikacijom daje do znanja da ga se sluša. Slušatelj zauzima položaj tijela koji ukazuje na zainteresiranost, usmjerava tijelo prema govorniku, uvažava osobni prostor pridržavajući se primjerenog razmaka. U javnom govoru verbalne vještine su od ključnog značaja (Patterson, 2006). Mihić (2008) ističe kako su brojni primjeri uspješnih prodavača koji su postigli iznimne uspjehe u prodaji upravo zahvaljujući svojim verbalnim vještinama. Ukoliko je govornik pripremljen, posjeduje vještine dobrog izražavanja i paraverbalne komunikacije izglednije je kako će duže vrijeme zadržati pažnju slušatelja što će se odraziti na njegovu uspješnost usvajanja upućenih mu informacija.

${ }^{3}$ https://www.enciklopedija.hr/natuknica.aspx?id=27686 


\subsubsection{Neverbalna komunikacija}

Neverbalna komunikacija predstavlja nesvjesni dio izražavanja. Neverbalni dio komunikacije otkriva i ono što govornik nije spreman otkriti te time značajno utječe na ukupan dojam slušatelja. Ovaj tip komunikacije sadrži različite komponente kao što su kontakt očima, izrazi lica, gestikulacija, položaj tijela, ton glasa, brzina govora, fizički kontakt kao što je rukovanje, stil odijevanja, šminka, frizura i mnoge druge. Davne 1872. godine Charles Darwin je proveo istraživanje o sličnosti između osjećaja čovjeka i osjećaja životinja nazvavši ga „Izražavanje osjećaja kod čovjeka i životinja". Od tada se provode brojna istraživanja na temu neverbalne komunikacije (Mandal, 2014, Calero, 2005). Neverbalna komunikacija zna biti toliko suptilna da osoba često nije svjesna na koji ju način prenosi. Istraživanje Charlesa Darwina je identificiralo devet različitih tipova neverbalne komunikacije. ${ }^{4}$ Ekspresije lica su poveznica među različitim kulturama kada je riječ o neverbalnoj komunikaciji. Svaka kultura ima svoje specifičnosti pa tako i u neverbalnom izražavanju. Izrazi lica tijekom izražavanja emocija, kao što su sreća, ljutnja, strah, zbunjenost i drugo, kod svakog pojedinca su slični. No, čest je slučaj kako je nešto prihvatljivo jednoj i potpuno neprihvatljivo drugoj kulturi. Na primjer Japanci se mogu naći uvrijeđenima ukoliko ih se gleda direktno u oči. Gestikulacija se odnosi na pokrete rukama. Pokreti su važni u prenošenju značenja bez upotrebe riječi. Uobičajene geste uključuju mahanje, pokazivanje i korištenje prstiju za označavanje numeričkih iznosa dok su ostale geste proizvoljne i povezane sa kulturom pojedine zemlje. Paraverbalna komunikacija podrazumijeva vokalnu komunikaciju koja nema poveznicu sa jezikom kojim osoba govori već je isključivo dio njene osobnosti. Neka osoba može imati dublji ili hrapav glas dok neka druga može imati visok i piskutav glas. Ton glasa ima utjecaja na zainteresiranost slušatelja. Ukoliko se govornik koristi glasnim tonom veća je šansa da izazove entuzijazam i interes kod slušatelja. Brojna su istraživanja utvrdila kako komuniciranje tihim tonom stvara dojam jednoličnosti što rezultira nezainteresiranošću i ostavlja cjelokupan loš dojam. Ton glasa ima utjecaj i na značenje onoga što govorimo. Ukoliko osoba "potištenim" tonom kaže kako se osjeća dobro, sugovornik može steći upravo suprotan dojam jer verbalno nije u jednoznačju s neverbalnim. Ne čudi tome činjenica kako pojedini stručnjaci smatraju kako artikulacija izgovora može puno više reći od riječi koje osoba izgovori. Matsumoto (2006) tvrdi kako je za arapske zemlje karakterističan glasan govor jer se potonji povezuje sa snagom dok se, primjerice u Brazilu, takav glasan ton može protumačiti kao izraženija zainteresiranost govornika za slušatelja. U Njemačkoj se, pak, povišeni tonovi u govoru tumače kao odraz autoriteta i samopouzdanja. Takvo ponašanje na Tajlandu bi se protumačilo kako je osoba uzrujana ili pak nervozna jer se ondje preferira tiši oblik komunikacije. Isto vrijedi i za Japance koji su u cijeloj svojoj komunikaciji dosta umjereniji od Amerikanaca i Europljana (McDaniel, 1993). Nadalje, položaj tijela može ukazivati na to koliko osoba vjeruje u ono što govori ili pak koliko je slušatelj zainteresiran za temu koju govornik izlaže. Osobni razmak je također dio neverbalne komunikacije. Potreba za njim se stvara na temelju socijalnih normi, kulture, okolnosti, osobnih karakteristika i razine ekstrovertiranosti. Kontakt očima ukazuje na to koliko smo zainteresirani, ljubazni ili koliko nas nešto privlači. On također ukazuje na iskrenost osobe koja govori. Ukoliko se izbjegava kontakt očima, navedeno stvara dojam neiskrenosti, nezainteresiranosti ili neljubaznosti. Dodir se može koristiti kao izraz ljubaznosti, empatije ili neke druge emocije. Osobni

${ }^{4}$ Verywell mind, Types of Nonverbal Communication https://www.verywellmind.com/types-of-nonverbal-communication-2795397 (posjećeno na dan 10.08.2021.) 
stil odnosno fizički izgled je prva komponenta koju slušatelj može uočiti. Istraživanja su pokazala da izgled ima veliki utjecaj na opći dojam. No, kriteriji koji definiraju dobar izgled razlikuju se ovisno o kulturi pojedinog naroda.

\section{Općenito o komunikaciji i javnom nastupu}

Brojni su autori koji u fokus svog istraživanja stavljaju komunikaciju. Prije više od pola stoljeća napisana su djela u kojima su autori pokušavali otkriti kako čovjek komunicira i kako se komunikacija mijenjala tijekom svih ovih godina (Biihler, 1934, 1965; Austin, 1962; Searle, 1969). Komunikacija se odnosi na međusobno izmjenjivanje informacija između dvije ili više osoba. U mnogim jezicima se može naći riječ "komunikacija“. Izvedena je od latinskoga pri-

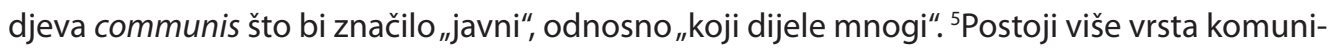
kacije no sve imaju zajednički cilj; stvoriti interakciju u kojoj se govornik i sugovornik mogu sporazumjeti. Komunikacija služi kako bi se prenijela neka informacija, izrazio stav ili osjećaj, zatražio odgovor i slično (Kunczik i sur., 2006). Komuniciranje se može manifestirati na verbaIan ili neverbalan način. Prvi oblici komunikacije se pojavljuju još u doba homo sapiensa (lat. mudri, razumni čovjek) kada su ondašnji praljudi počeli verbalno komunicirati. Kako ističe Calero (2005) prvi oblici neverbalne komunikacije vezivali su se uz izraze lica odnosno ispoljavali su se facijalnom ekspresijom. Nakon toga pojavljuju se i prvi oblici neverbalne komunikacije upotrebom različitih simbola. Javni nastup odnosi se na držanje govora pred određenom skupinom ljudi. On je u različitim oblicima prisutan među ljudima gotovo od samog početka ljudskog vijeka. Broji stručnjaci koji se bave javnim nastupom na temu poslovnog komuniciranja još se uvijek oslanjaju na postulate javnog komuniciranja nastalih iz vremena stare Grčke i Rima. Govor može imati različite namjene i sukladno tome biti različitog karaktera. Cilj nekog izlaganja može biti informiranje, motiviranje, zabavljanje ili utjecanje na slušatelje. Za vrijeme izlaganja govornik se koristi različitim pomagalima. To mogu biti razni podsjetnici ili vizualni dodaci poput npr. slajdova prezentacije. Svrha korištenja slajdova, koji osim glavnih pojmova često sadrže slike ili video uratke, jest prezentaciju učiniti zanimljivijom. Još u doba starih Grka javila se potreba za javnim nastupom unatoč tome što su u to vrijeme didaktička pomagala bila nedostupna. Kao rezultat tog nastojanja razvile su se brojne metode koje se i danas primjenjuju u javnom nastupu i još uvijek su predmet izučavanja brojnih znanstvenika ali i praktičara. Stari su Grci koristili javni nastup kao metodu uvjeravanja građana u različite ideje. Građani bi se tijekom javnih okupljanja argumentirano protivili, prihvaćali ideje ili pak sugerirali nešto sasvim drugo od onoga što im je prezentirano. Ovakav pristup zahtijevao je od govornika da neprestano produbljuju i razvijaju svoja znanja i vještine uvjeravanja korištene u javnom nastupu. Grci su koristili termin "retorika" što znači umijeće izražavanja. Većina učitelja javnog nastupa bili su stari Grci a njihove metode su i danas predmet izučavanja brojnih škola retorike. Etos, logos i patos bile su tri Aristotelove kategorije povezane s vještinom uvjeravanja. Ethos (grčki ĩ položenje) se odnosi na vjerodostojnost govornika i uključuje tri dimenzije: kompetentnost, pouzdanost i dinamiku. Dvije najizražajnije dimenzije vjerodostojnosti su kompetentnost i

${ }^{5}$ Izvor: Online Etymology Dictionary, natuknica common http://www.etymonline.com/index.php?term=common\&allowed_in_frame=0 (posjećeno na dan 09.08.2021.) 
pouzdanost. Kompetencija se odnosi na govornikovu stručnost u odnosu na temu koju izlaže. Kompetentni govornici trebaju dobro poznavati sadržaj svog govora i biti sposobni slušateljstvu učinkovito prenijeti isti sadržaj. Pouzdanost se odnosi na stupanj u kojem publika doživljava govornika kao osobu koja prenosi točne, vjerodostojne informacije na prihvatljiv način. Stvaranje dojma pouzdanosti govornika proizlazi iz sadržaja govora i same osobnosti govornika. Dinamika se odnosi na stupanj animacije govornika. Dvije komponente dinamike su karizma i energija. Karizma se odnosi na individualne karakteristike i konkretne kvalitete povezane sa osobnošću koje govornika čine karizmatičnim. Karizmatični ljudi obično su svjesni karizme koju posjeduju.

\section{Metodologija istraživanja i izvori prikupljanja podataka}

Podaci o stavovima ispitanika o upotrebi neverbalne komunikacije u javnom nastupu prikupljeni su online anketnim upitnikom. Distribucija anketnog upitnika se odvijala metodom "snježne grude" (Baltar i Brunet, 2012) prema kojoj ispitanik, nakon što ispuni anketu, istu prosljeđuje dalje. Anketni upitnik se distribuirao putem mobilne aplikacije WhatsApp i društvenih mreža Facebook i Instagram. Upitnik se sastojao od dva dijela. Pitanja su sastavljena tako da se na njih odgovaralo višestrukim odabirom ili odabirom jedne od ponuđenih izjava na Likertovoj ljestvici od pet stupnjeva intenziteta. Istraživanje se provodilo dvadeset dana, i to u periodu od 01.03.2021. godine do 20.03.2021. godine. Anketa je bila u potpunosti anonimna i sastojala se od devetnaest pitanja i jednog video isječka. Ispitanici su mogle biti sve punoljetne osobe, državljani Republike Hrvatske stariji od 18 godina.

\subsection{Opis instrumenata istraživanja}

Na početku anketnog upitnika, u uvodu, objašnjeni su ciljevi anketnog istraživanja kako bi se ispitanike uvelo $u$ istraživanu tematiku. Prva skupina pitanja bila su pitanja vezana uz demografske osobine ispitanika a odnosila su se na spol, dob i formalno završeni stupanj obrazovanja. Obilježja ispitanika važna su za donošenje zaključka imaju li spol i dob ispitanika utjecaj na ukupan dojam o govornici. Nakon demografskih pitanja od ispitanika se tražilo da klikom na link https://www.youtube.com/watch?v=AvHMzFtX4kY pogledaju video isječak objavljen na društvenoj mreži You Tube u trajanju od 1:38 minuta. Navedeni isječak je prikazivao javni nastup tadašnje predsjednice Kolinde Grabar Kitarović u sklopu predizborne kampanje za predsjednika/icu Republike Hrvatske. Nastup se održao u Osijeku 15.12.2019. Nakon što su odgledali video isječak od ispitanika se tražilo da odgovore na pitanja vezana uz njihov ukupan dojam o govornici i održanom govoru s posebnim naglaskom na njihova zapažanja vezana uz neverbalnu komunikaciju. Za ispunjavanje upitnika i gledanje video isječka bilo je potrebno izdvojiti otprilike do pet minuta vremena. Anketni upitnik sastojao se od dva dijela. Pitanja su sastavljena na način da ispitanici daju svoj odgovor na Likertovoj ljestvici od pet stupnjeva intenziteta gdje je ispitanicima ponuđeno ocijeniti određene elemente neverbalnog ponašanja govornice na temelju ponuđenog video isječka. Prvi dio upitnika odnosio se na opće demografske podatke (dob, spol i stupanj obrazovanja) dok se drugi dio upitnika odnosio na pitanja u kojima se od ispitanika tražilo prenijeti svoja zapažanja o neverbalnim i paraverbalnim znakovima komunikacije promatrane političarke u video 
isječku. Drugi dio anketnog upitnika sastojao se od šesnaest pitanja. Pitanja su sastavljena na način da ispitanici iznesu svoja zapažanja o nastupu govornice.

\subsection{Uzorak i struktura istraživanja}

Uzorak ispitanika bio je prikladan (Mejovšek, 2005) kako bi zadovoljio istraživački cilj tj. generalizirao saznanja o populaciji na temelju zapažanja o uzorku (Scharfenberg i sur., 2006). U istraživanju je korištena metoda snježne grude (engl. snowball) u kojoj svaki ispitanik identificira sljedećeg ispitanika. Kao glavni problem internetskih istraživanja koji mogu utjecati na reprezentativnost uzorka, kako ističu brojni autori (Dillman, 2007; Couper i Bosnjak, 2010) su: pogreška pokrivenosti, pogreška uzorkovanja, pogreška neodaziva i pogreška mjerenja. U uzorku su većinom bili zastupljeni mlađi ispitanici od 18 do 30 godina sa završenom srednjom školom $(44,8 \%)$ što je i očekivano s obzirom da se starije osobe slabije služe internetom (Seybert, 2012). Ispitanici su većinom bili ženskog spola što se objašnjava činjenicom kako se žene sklonije ispunjavati online ankete od muškaraca (Smith, 2008; Kwak i Radler, 2002; Underwood i sur., 2000). Anketa je bila anonimna, a ispunjavati su je mogle sve punoljetne osobe s prebivalištem u Republici Hrvatskoj. Ukupno je 154 ispitanika pogledalo video isječak o nastupu tadašnje predsjednice Kolinde Grabar Kitarović u Osijeku. Svi ispitanici žive na području Republike Hrvatske te imaju pristup Internetu. Upitnik se najvećim dijelom prosljeđivao putem mobilne aplikacije WhatsApp i društvenih mreža Facebook i Instagram.

\section{Rezultati istraživanja}

Sudeći prema broju objava u medijima (javna televizija i lokalne televizije, društvene mreže, dnevne i tjedne tiskovine) nakon održanog predizbornog političkog skupa sada tadašnje predsjednice Kolinde Grabar Kitarović, navedeni govor je uzburkao i podijelio mišljenja javnosti. Anketu je u konačnici ispunilo 154 ispitanika. Od ukupnog broja ispitanika $72,1 \%$ je bilo žena, odnosno njih 111, dok je muškaraca bilo 27,9\% odnosno njih 43.

\section{Grafikon 1. Struktura ispitanika prema spolu}

Vaš spol:

154 responses

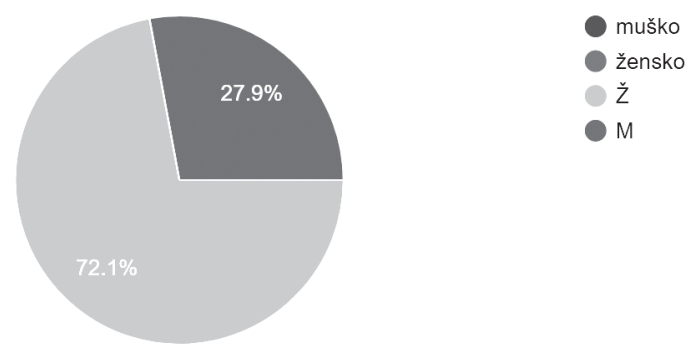

Izvor: Rezultati anketnog istraživanja autorica 
Najveći broj ispitanika imao je završenu srednju stručnu spremu (njih 44.8\%, odnosno njih 69). Nešto manje ispitanika (36,4\%), imalo je završenu višu stručnu spremu, odnosno njih 52. Visoku stručnu spremu imalo je 18,8\% ispitanika odnosno njih 29. Najmanji je broj ispitanika je sa završenom osnovnom školom kao njvišim stupnjem formalnog obrazovanja. Njih je bilo 6 odnosno 3,9\%.

\section{Grafikon 2. Struktura ispitanika prema završenom stupnju formalnog obrazovanja Vaš formalni završeni stupanj obrazovanja: \\ 154 responses}

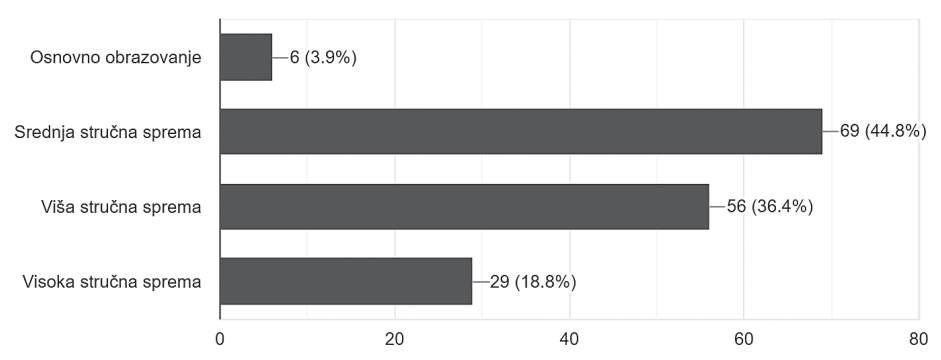

Izvor: Rezultati anketnog istraživanja autorica

Ispitanici su bili različitih dobnih skupina. Najveći broj ispitanika pripadao je dobnoj skupini od 18-30 godina.

\section{Grafikon 3. Struktura ispitanika prema životnoj dobi}

Vaša dob:

154 responses
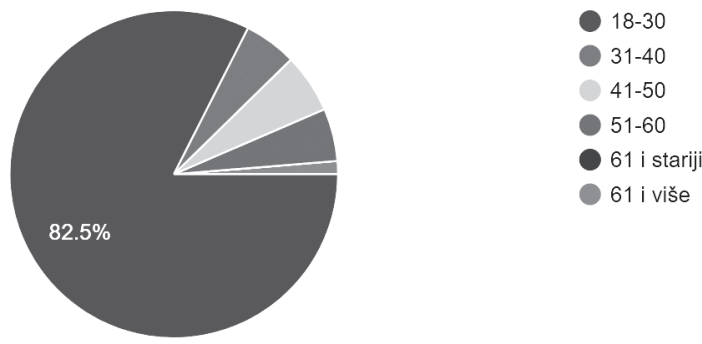

Izvor: Rezultati anketnog istraživanja autorica

Početak anketnog upitnika sastavljen je od pitanja na koja se odgovaralo pomoću Likertove

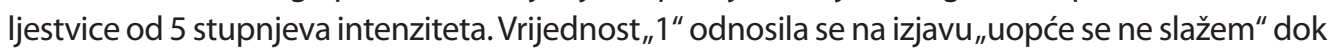
se vrijednost „5" odnosila na izjavu „u potpunosti se slažem”. Od ukupnog broja ispitanika njih 46 odnosno $29,9 \%$ smatra gestikulaciju rukama govornice neprimjerenom i u neskladu s onim što govori. Samo njih 17 odnosno 11\% smatra gestikulaciju primjerenom i u skladu s porukom koju govornica nastoji prenijeti. Čak više od četvrtine $(26,6 \%)$ ispitanika, odnosno njih 41 , se slaže 
kako izraz lica govornice ne odaje dojam smirenosti i samouvjerenosti, dok je postotak onih koji se u potpunosti slažu kako izraz lica odaje dojam smirenosti i samouvjerenosti puno manji (11\% odnosno 17 ispitanika). Također 25,3\% odnosno 39 ispitanika na istu izjavu ima neutralno mišljenje. Ispitanici su u najvećem postotku (26,6\% odnosno 41 ispitanik) na skali od 1 do 5 izabrali vrijednost „, 3 " (što označava neutralno mišljenje) na izjavu da kontaktom očima govornica stvara dojam iskrenosti i povjerenja. Sa izjavom da su paraverbalna komunikacija govornice (ton, brzina, ritam i jačina) izgovora bili su primjereni i u skladu s porukom koju govornica nastoji prenijeti uopće se ne slaže veći postotak ispitanika ( $27,3 \%$ odnosno 42 ispitanika), dok se samo 12,3\% (19 ispitanika) u potpunosti slaže. Čak 31,2\%, odnosno 48 ispitanika ukupan nastup govornice ocjenjuje kao izrazito neuspješan, a samo 6,5\%, odnosno 10 ispitanika smatra kako je govor bio izrazito uspješan. Kako bi ispitanici opravdali svoj stav o nastupu govornice naveli su komponente koje su utjecale na njihov cjelokupan pozitivan ili negativan dojam.

\section{Grafikon 4. Komponente utjecaja na ukupan dojam o govornici}

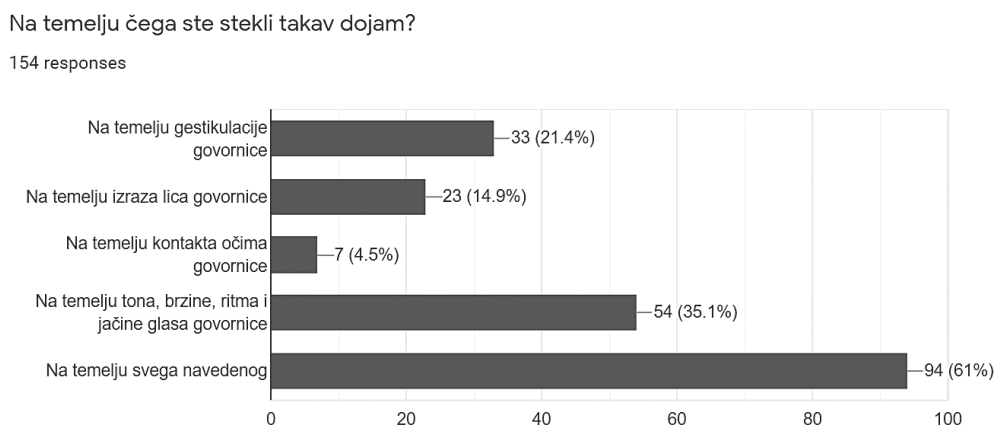

Izvor: Rezultati anketnog istraživanja autorica

Na sljedećoj slici vrijednost "1“ predstavlja „izrazito negativno", a vrijednost " 5 " „izrazito pozitivno".

\section{Grafikon 5. Utjecaj načina izlaganja na opći dojam o govornici}

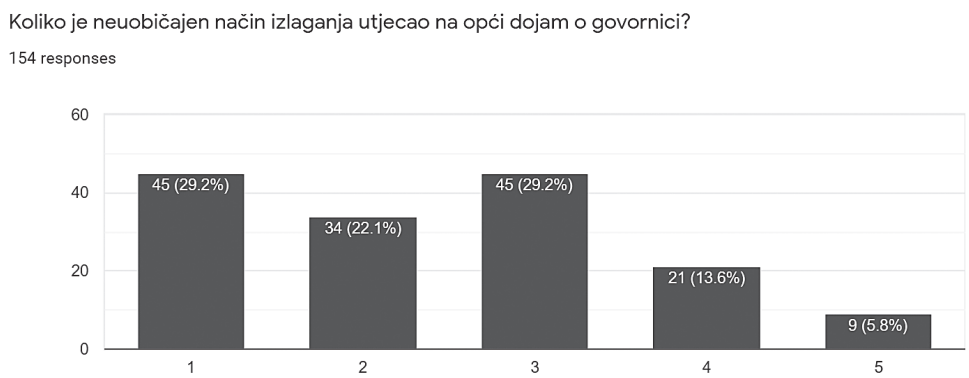

Izvor: Rezultati anketnog istraživanja autorica

Na temelju kontakta očima odnosno pogleda govornice 42,9\% odnosno 66 ispitanika smatra kako se govornica nalazi pod stresom. Njih 20,8\%, odnosno 32 ispitanika mišljenja je kako je 
govornica umorna, dok 16,9\%, odnosno 26 ispitanika zaključuje kako je nezadovoljna. Samo njih 9,1\% (14 ispitanika) doživljava govornicu kao veselu i entuzijastičnu dok ostatak, njih $10,4 \%$ odnosno 16 ispitanika, smatra kako je iskrena i iracionalna.

Na temelju izraza lica govornice 35,1\%, 54 ispitanika izjasnilo se kako djeluje nesigurno, $26,6 \%$ odnosno 41 ispitanik misli kako je zbunjena, 14,9\% to jest 23 ispitanika smatra kako djeluje optimistično, dok 9,7\%, odnosno 15 ispitanika smatra kako govornica ostavlja dojam staloženosti. Najmanji broj ispitanika, njih 9 odnosno 5,8\%, izjasnio se kako izraz lica govornice odražava zabrinutost ili nezadovoljstvo.

Na pitanje kakav dojam ispitanici imaju na temelju boje glasa govornice na skali od 1 do 5 , gdje vrijednost „1" predstavlja izjavu „Odlučan stav, povjerenje, sigurnost i entuzijazam", a vrijednost " 5 " „Neodlučan stav, nepovjerenje, nesigurnost i malodušnost" najviše je ispitanika odabralo vrijednost "3“ (30,5\%, 47 ispitanika) i vrijednost ", 4 " (29,2\%, 45 ispitanika) sugerirajući kako govornica ostavlja neutralan dojam.

\section{Grafikon 6. Utjecaj gestikulacije rukama na dojam o govornici}

\section{Gestikulacija rukama govornice stvara dojam}

154 responses

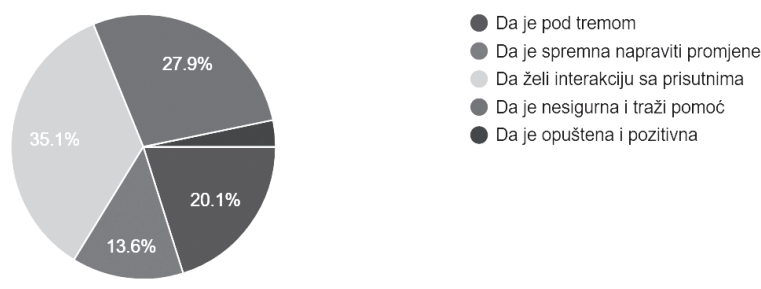

Izvor: Rezultati anketnog istraživanja autorica

\section{Grafikon 7. Utjecaj položaja tijela na dojam o govornici}

\section{Položajem tijela govornica stvara dojam \\ 154 responses}
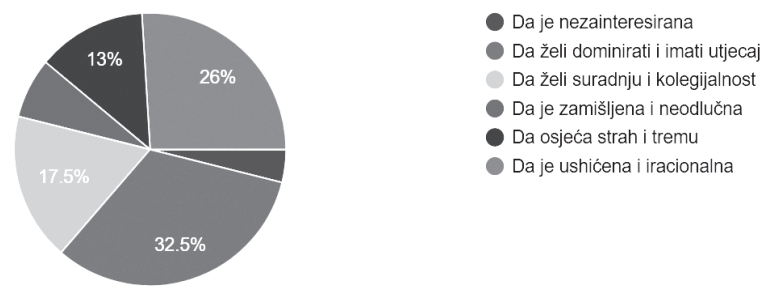

Izvor: Rezultati anketnog istraživanja autorica

Od ispitanika se tražilo da na ljestvici od pet stupnjeva intenziteta (gdje vrijednost "1" predstavlja „potpuno primjereno" a vrijednost ", 5 " "potpuno neprimjereno") ocijene različite elemente neverbalne komunikacije.

Interakciju pogledom, najveći broj ispitanika, njih 65 , odnosno 42,2\%, ocijenilo je vrijednošću „3“ što predstavlja neutralan stav. 
Izraz lica također je u najvećem postotku ocijenjen vrijednošću „3“ (33,1\%, odnosno 51 ispitanik). Jačinu govora govornice njih 31,2\% odnosno 48 ispitanika ocijenilo je vrijednošću „3“.

Tempo govora govornice ispitanici su najviše ocijenili vrijednošću „3" $(26,6 \%)$, što znači da imaju neutralan stav o istom elementu, dok je podjednako ispitanika (24\%) dalo vrijed-

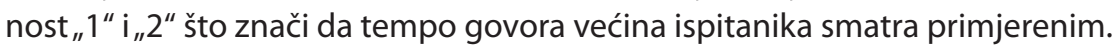

Gestikulacija rukama govornice ocjenjena je u najvećem broju kao potpuno neprimjerena (40,3\%, odnosno 62 ispitanika).

Stav i položaj tijela ispitanici su u najvećoj mjeri ocijenili vrijednošću „2" (27,3\%, odnosno 42 ispitanika) i vrijednošću „1“ (24,7\%, odnosno 38 ispitanika). Nešto manje ispitanika odgovarajući na ovo pitanje odabralo je vrijednost „3" (njih 22,1\%, odnosno 34 ispitanika).

Na ljestvici od 1 do 5 , gdje vrijednost "1" predstavlja najslabiji intenzitet, a vrijednost "5" najsnažniji intenzitet od ispitanika se tražilo da ocijene pojedine emocije kod govornice.

Grafikon 8. Prisustvo emocije "zadovoljstvo" kod govornice

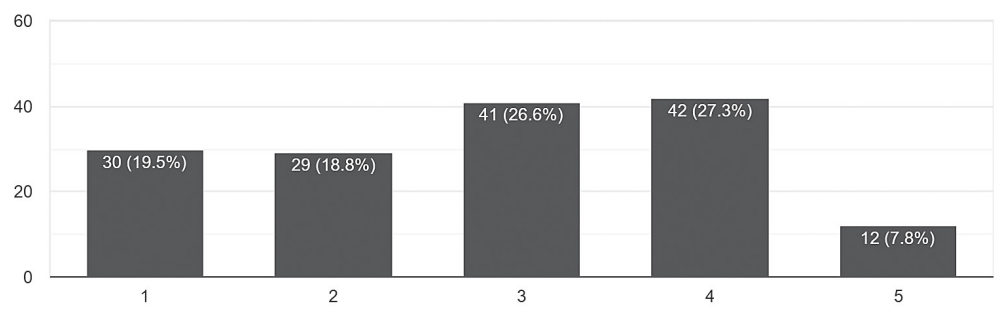

Izvor: Rezultati anketnog istraživanja autorica

Grafikon 9. Prisustvo emocije "ljutnja“ kod govornice

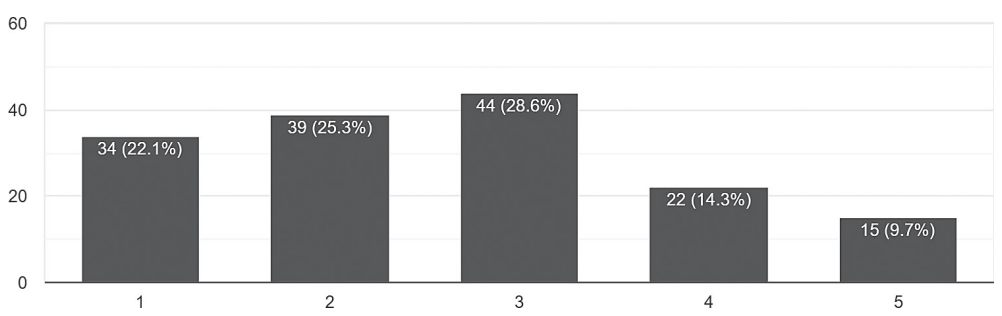

Izvor: Rezultati anketnog istraživanja autorica

Grafikon 10. Prisustvo emocije "gađenje" kod govornice

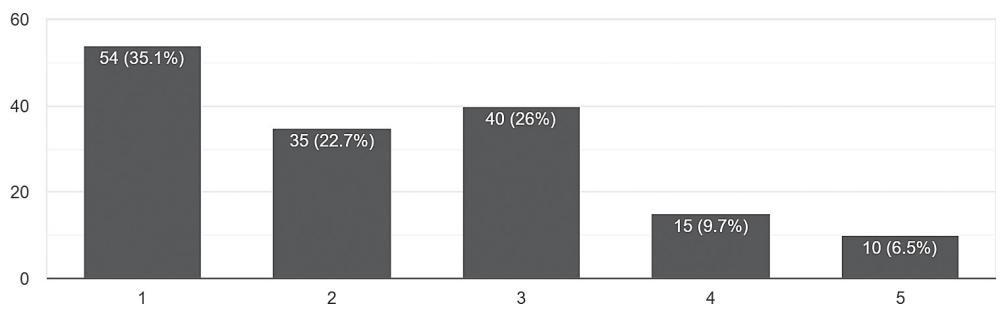

Izvor: Rezultati anketnog istraživanja autorica 
Grafikon 11. Prisustvo emocije "neutralno" kod govornice

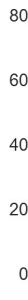

80

60

40

20

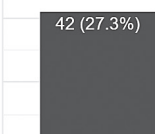

$0+1$

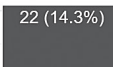

2

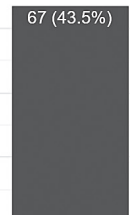

3

\section{$14(9.1 \%)$}

4

Izvor: Rezultati anketnog istraživanja autorica

Grafikon 12. Prisustvo emocije „iznenađenosti" kod govornice

60

60

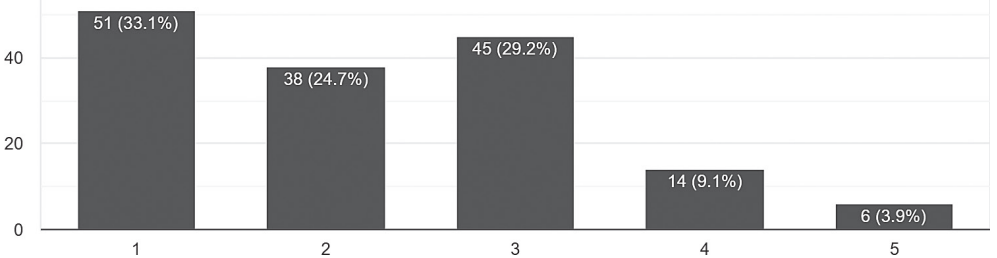

Izvor: Rezultati anketnog istraživanja autorica

Grafikon 13. Prisustvo emocije „sreća” kod govornice

60

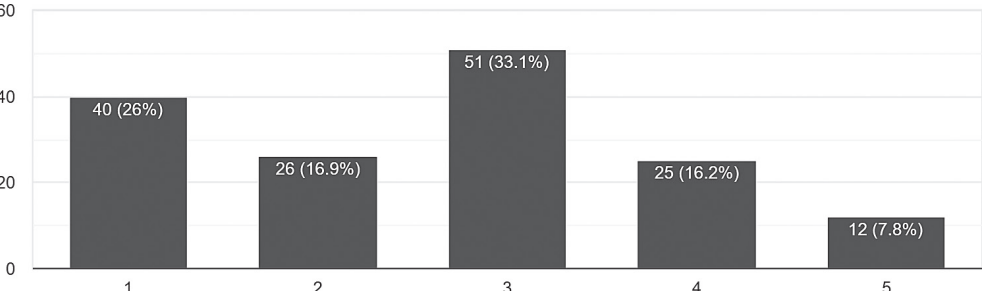

Izvor: Rezultati anketnog istraživanja autorica

Grafikon 14. Prisustvo emocije „strah" kod govornice

60

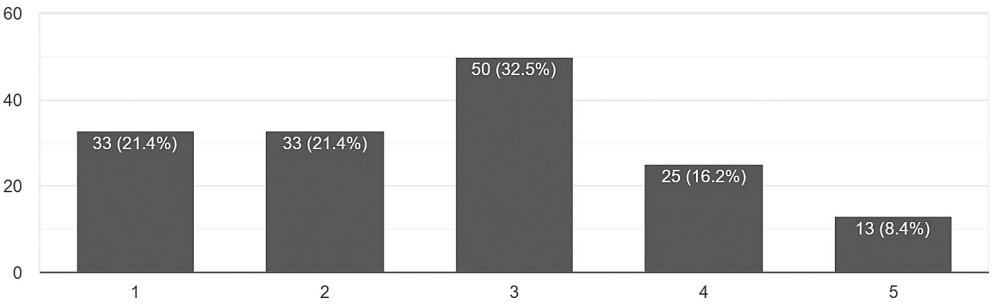

Izvor: Rezultati anketnog istraživanja autorica 
Grafikon 15. Prisustvo emocije "tuga“ kod govornice

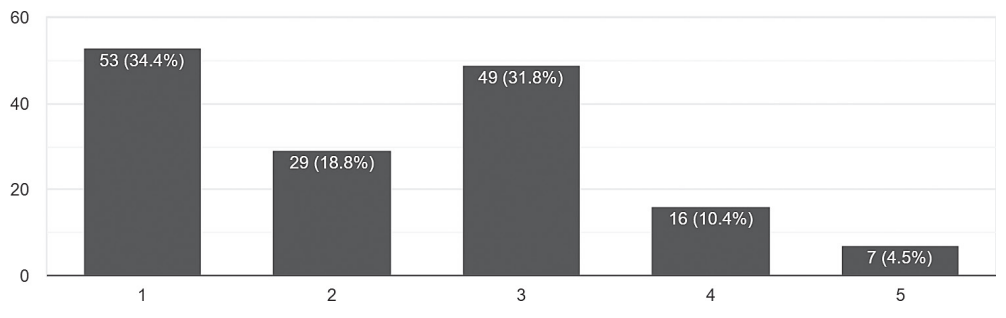

Izvor: Rezultati anketnog istraživanja autorica

Na skali od 1 do 5 ispitanici su trebali ocijeniti ukupan dojam o govornici. Vrijednost „1“ odnosila se na izjavu „Nepouzdana, neprofesionalna, antipatična i neiskrena“, dok se vrijednost "5" odnosila na izjavu „Pouzdana, profesionalna, odlučna i samouvjerena".

Njih 33,8\% odnosno 52 ispitanika ocijenilo je govornicu vrijednošću „3“ što znači da joj je pridalo vrijednost koja predstavlja neutralno mišljenje, 23,4\% odnosno 36 ispitanika pridalo joj je vrijednost „1“ što znači da su mišljenja kako je govornica nepouzdana, neprofesionalna, antipatična i neiskrena. Njih 20,1\% (odnosno 31 ispitanik) odabrao je vrijednost "2". Njih 16,9\% (odnosno 26 ispitanika) odabralo je vrijednost "4" a samo 5,8\%, odnosno samo 9 ispitanika odabralo je vrijednost " 5 " što znači da je na samo pet ispitanika govornica ostavila dojam pouzdane i profesionalne osobe.

Na skali od 1 do 5 gdje se vrijednost „1" odnosi na izjavu „U potpunosti se ne slažem", a vrijednost " 5 " na izjavu „U potpunosti se slažem“ ispitanici su izrazili svoj stav o neverbalnoj komunikaciji govornice.

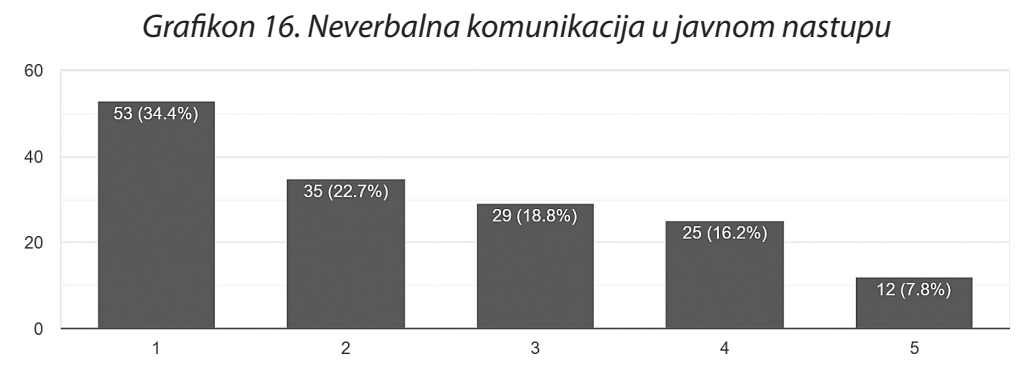

Izvor: Rezultati anketnog istraživanja autorica

Više od polovice ispitanika (odabravši izjave označene vrijednošću „1“ i „2") smatra kako neverbalna komunikacija govornice nije uspjela uvjeriti slušatelje $u$ istinitost onoga što govori. Naime, njih 53, odnosno 34,4\% ispitanika izjavilo je kako se u potpunosti ne slažu s izjavom kako neverbalna komunikacija govornice pomaže uvjeriti slušatelja u istinitost onoga što govornica iznosi, dok se samo njih 12, odnosno, 7,8\% u potpunosti složilo s navedenom izjavom. 


\section{Zaključak}

Neverbalna komunikacija zauzima značajnu ulogu u javnom nastupu. Ona može ostaviti toliko snažan dojam na slušatelja da se može dogoditi da u potpunosti promijeni značenje poruke koju se želi odaslati. Cilj neverbalne komunikacije jest nadopuniti ono što je verbalno rečeno, upotpuniti i ispuniti ono što je izgovoreno bez nepotrebnog ponavljanja. Brojni su čimbenici koji utječu na neverbalnu komunikaciju; izgled govornice, položaj i stav tijela, šminka, frizura, odjeća, samopouzdanje i sl. Pretpostavka ovog istraživanja je bila kako ispitanici zapažaju znakove neverbalne i paraverbalne komunikacije u javnom nastupu te kako veći značaj pridaju neverbalnoj u odnosu na verbalnu komunikaciju. Analizom rezultata dobivenih anketnim istraživanjem, došlo se do zaključka kako jest uistinu puno važnije, kod javnog nastupa, obratiti pažnju na to „kako se govori“ umjesto na „što se govori”. Ispitanici primjećuju neverbalnu komunikaciju i pridaju joj izniman značaj. Stoga ne čudi činjenica kako je moguće da neverbalna komunikacija unese „pomutnju“ u stav slušatelja na ukupan dojam o govorniku. To ukazuje na neupitnu stvarnost koliko je važna neverbalna komunikacija i koliko joj slušatelji pridaju pozornost. U ovom radu je na primjeru analize javnog nastupa u sklopu predizbornog skupa bivše predsjednice Republike Hrvatske prikazano kako govornica nije uspjela uvjeriti slušatelje $u$ istinitost onoga što je pokušala prenijeti. Tome uzrok, prema rezultatima istraživanja, treba tražiti u paraverbalnoj komunikacija govornice koju su ispitanici ocijenili kao poprilično neuobičajenu što se u konačnici odrazilo i na ukupan dojam govornice. Stoga je od iznimne važnosti posebnu pažnju posvetiti obrazovanju mladih naraštaja kako bi se obučili vještinama verbalne, paraverbalne i neverbalne komunikacije.

\section{LITERATURA}

1. Austin, J. L., 1962. How to Do Things with Words Cambridge Harvard University Press.

2. Baltar, F. i Brunet, I., 2012. Social research 2.0: virtual snowball sampling method using Facebook. Internet research.

3. Biihler, K., 1934. 1965. Sprachtheorie, Fischer, Stuttgart.

4. Brindley, P. G., I Reynolds, S. F., 2011. Improving verbal communication in critical care medicine. Journal of critical care, 26(2), 155-159.

5. Calero, H. H., 2005. The power of nonverbal communication: How you act is more important than what you say. Silver Lake Publishing.

6. Couper, M. P., Bosnjak, M., 2010. Internet Surveys. U P. V. Marsden, J. D. Wright (ur.), Handbook of Survey Research (

7. 527-550). Emerald Group Publishing.

8. Dillman, D. A., 2007. Mail and internet surveys: The Tailored Design Method 2007 update with new internet, visual, and mixed-mode guide. Hoboken, New Jersey: John Wiley \& Sons, Inc.

9. Kunczik, M., Zipfel, A., Rešetar i A., Sušilović, D., 2006. Uvod u znanost o medijima i kommunikologiju.

10. Kwak, N., \& Radler, B., 2002. A comparison between mail and web surveys: response pattern, respondent profile, and Data quality. Journal of Official Statistics, 18(2), 257-273.

11. Lucanin, D., Lucanin. D. J., Communication skills in health care, Zagreb, Naklada Slap, 2010. 17. 
12. Mandal, F. B., 2014. Nonverbal communication in humans. Journal of human behavior in the social environment, 24(4), 417-421.

13. Matsumoto, D., 2006. Are cultural differences in emotion regulation mediated by personality traits?. Journal of cross-cultural psychology, 37(4), 421-437.

14. McDaniel, E. R., 1993. Japanese Nonverbal Communication: A Review and Critique of Literature.

15. Mehrabian, A., 1967. Orientation behaviors and nonverbal attitude communication. Journal of communication.

16. Mejovšek, M., 2013. Metode znanstvenog istraživanja: u društvenim i humanističkim znanostima. Slap.

17. Mihić, M., 2008. Upravljanje osobnom prodajom: Vještine prodaje i pregovaranja. Ekonomski fakultet u Splitu.

18. Ng, S. H. i Bradac, J. J. 1993. Power in language: Verbal communication and social influence. Sage Publications, Inc.

19. Patterson, V. L. M. M. L., 2006. The Sage handbook of nonverbal communication. Sage.

20. Petar, S., 2009. Say it louder and louder. M.E.P. Consult, 2009., 28.

21. Scharfenberg, F. J., Bogner, F. X. i Klautke, S., 2006. The suitability of external control-groups for empirical control purposes: A cautionary story in science education research. The Electronic Journal for Research in Science \& Mathematics Education.

22. Searle, J. R. i Searle, J. R. 1969. Speech acts: An essay in the philosophy of language (Vol. 626). Cambridge university press.

23. Seybert, H., 2012. Internet Use in Households and by Individuals in 2012. Eurostat, 13. prosinca 2012.

24. Smith, G., 2008. Does gender influence online survey participation?: A record-linkage analysis of university faculty online survey response behavior. ERIC Document Reproduction Service No. ED 501717.

25. Španjol-Marković, M., 2008. Manual for Public Speaking and Business Presentation, Zagreb, Ciceron komunikacije d.o.o., 75.

26. Underwood, D., Kim, H., and Matier, M., 2000. To mail or to Web: Comparisons of survey response rates and respondent characteristics. Paper presented at the 40th Annual Forum of the Association for Institutional Research, Cincinnati, OH, May 21-24, 2000. 
Summary

\section{NON-VERBAL COMMUNICATION AS A PERSUASIVE TOOL IN PUBLIC APPEARANCE}

In everyday communication, consciously or unconsciously, we use non-verbal communication to convey the message to the interlocutor in the most effective way, express emotions, impressions or convince him of our views. Nonverbal communication involves eye contact, facial expression, posture and body position, hand gestures, tone of voice, and touch. Personal appearance also belongs to one type of nonverbal communication. For example, the dressing style leaves an impression on the interlocutors, which can significantly impact the overall presentation. Public speaking involves presenting certain information to a larger group of listeners. Such presentation may be prepared, unprepared, formal, informal, spontaneous or structured. In public speech and verbal speech, non-verbal parameters of presentation are also of great importance. They represent a crucial tool used to not only convince listeners of the reliability and correctness of what is being said but also to gain their attention to keep the listener's interest present throughout the presentation. For this reason, non-verbal communication is essential as a subject of study within public speaking. Overall nonverbal communication, as well as speaking skills, can be improved through practice. By using different persuasion techniques, it is possible to influence the listeners and bring them closer to the views and message being conveyed to them. This paper sought to explore the impact of nonverbal communication as a tool of persuasion in public speaking. The paper analyzes what and to what extent nonverbal expression impacts the overall impression of the speaker. The empirical part of the paper is based on the analysis of opinions and attitudes of respondents collected by the survey on nonverbal communication. The results obtained by processing the survey questionnaire indicate that non-verbal expression significantly impacts the overall impression of a person who conveys a specific message through public speech. The impression gained may ultimately leave a generally negative or positive attitude towards the speaker, and the fact that nonverbal communication often leaves a stronger impression on the listener's attitude towards the speaker than verbal communication has been confirmed.

Keywords: nonverbal communication, verbal communication, public speaking, persuasion tools. 